\title{
INFLUENCE OF THE PARTICLE SIZE DISTRIBUTION OF SILICA FLOUR ON THE MECHANICAL AND MICROSTRUCTURAL PROPERTIES OF OIL WELL CEMENT PASTE EXPOSED TO HTHP CONDITIONS
}

\author{
ZHIYI XIE*, ${ }^{\#}$ XIAO YAO*, ** \\ *College of Materials Science and Engineering, Nanjing Tech University, \\ Nanjing 210009, People's Republic of China \\ **Jiangsu National Synergetic Innovation Center for Advanced Materials, Nanjing Tech University, \\ Nanjing 210009, People's Republic of China \\ "E-mail: yaoxiao@njtech.edu.cnd
}

Submitted February 14, 2019; accepted April 3, 2019

Keywords: Silica, Particle size, Xonotlite, Crystallinity, Microstructure

\begin{abstract}
Silica flour is used to mitigate the strength retrogression and microstructure degradation problems of oil well cement paste in high temperature wells. This study investigates the effects of the particle size distribution of silica flour on the thermal stability of cement paste. After 7 days of hydrothermal curing at $80^{\circ} \mathrm{C}$, the cement paste was exposed to further aging for 7 or 28 days under high temperature and high pressure (HTHP) conditions in a sealed chamber at $260{ }^{\circ} \mathrm{C}\left(500{ }^{\circ} \mathrm{F}\right)$ and $21 \mathrm{MPa}(2900 \mathrm{psi})$. The results show that 43\% silica flour by weight of cement (BWOC) mitigates the strength degradation of silica-stabilized Portland cement (SSPC), and course silica flour (63.13 and $48.25 \mu \mathrm{m})$ maintains the strength stability of SSPC better than fine silica flour $(3.25 \mu \mathrm{m})$. The transformation of $C-S-H$ gel to xonotlite in SSPC was influenced by the silica particle size. The relatively fine silica flour $\left(d_{50}=3.25 \mu \mathrm{m}\right)$ accelerates the consumption of calcium hydroxide during the pozzolanic reaction, resulting in a poorer strength stability of SSPC than the courser silica flour $\left(d_{50}=63.13\right.$ and $48.25 \mu \mathrm{m})$. The silica flour with an average particle size of $48.25 \mu \mathrm{m}$ is more conducive to crystallization of xonotlite on the crystal plane corresponding to a diffraction angle of $25.5^{\circ}$ than the other size silica flour.
\end{abstract}

\section{INTRODUCTION}

In the petroleum industry, crude oil is continuously extracted from oilfields through oil wells. The performance of an oil well over its entire life is closely related to the integrity of the cement sheath [1]. As shown in Figure 1, the cement sheath formed between the casing and the formation is crucial for the well zonal isolation $[2,3,4]$. For cementing high temperature wells, silica is usually incorporated into oil well cement (OWC) slurry with the aim of mitigating the strength retrogression of hardened cement paste at $110^{\circ} \mathrm{C}\left(230^{\circ} \mathrm{F}\right)$ or higher temperatures [5]. Without silica incorporation, the deteriorative transformation of the calcium silicate hydrate $(\mathrm{C}-\mathrm{S}-\mathrm{H})$ gel phase formed in the hydrated cement paste to $\alpha$-dicalcium silicate hydrate $\left(\alpha-\mathrm{C}_{2} \mathrm{SH}\right)$ leads to a sharp strength decline [6-8]. When silica flour is added into the cement paste to reduce the lime-to-silica $(\mathrm{Ca} / \mathrm{Si})$ ratio of hydration products, more thermally stable phases, such as $14 \AA$ tobermorite and xonotlite, will be formed and mitigate the strength degradation under HTHP conditions [5]. According to previous research, when the $\mathrm{Ca} /$ $\mathrm{Si}$ ratio is approximately 1.0 and the temperature is above $150{ }^{\circ} \mathrm{C}\left(302{ }^{\circ} \mathrm{F}\right)$, the main hydration product is xonotlite $[1,5,8]$.

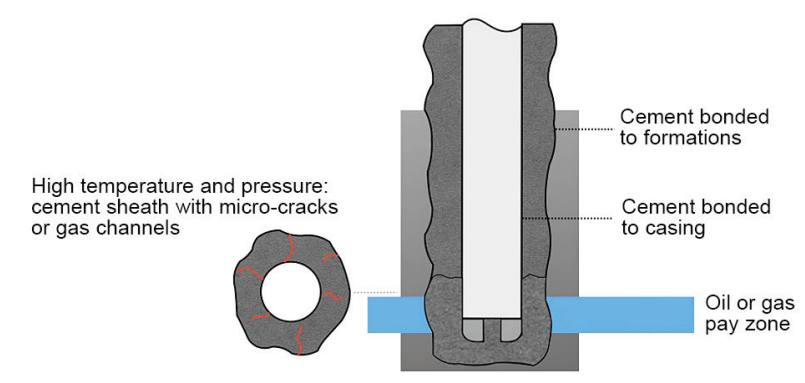

Figure 1. The influence of HTHP on a cement sheath.

Xonotlite is a type of crystalline phase transformed from precursor $11 \AA$ tobermorite at approximately $140{ }^{\circ} \mathrm{C}\left(284^{\circ} \mathrm{F}\right)$ [9-11]. It is an excellent heat-insulation material formed after hydration of tricalcium silicate at $200{ }^{\circ} \mathrm{C}$ and 600 bar for 4 days with silica addition (water/ cement $=0.55$; cement $/$ silica $=1.5)[12,13]$. Black et al. investigated the influence of synthesis conditions on the structure and morphology of xonotlite. They reported that a high synthesis temperature $\left(250^{\circ} \mathrm{C}\right)$ and a longer hydrothermal treatment duration (two weeks) will contribute to perfect xonotlite morphology [14]. Hsiang et al. explored the effect of the prereaction temperature $\left(40,60\right.$ and $\left.80^{\circ} \mathrm{C}\right)$ on the crystallization, microstructure 
and formation of xonotlite. Their conclusion was that the prereaction temperature had no influence on the formation of xonotlite [9]. Liu et al. studied the effect of the concentration of $\mathrm{Na}^{+}$on the crystalline phase composition and morphology of xonotlite in the $\mathrm{CaO}$ $-\mathrm{SiO}_{2}-\mathrm{H}_{2} \mathrm{O}$ system. The conclusion was that the content of $\mathrm{Na}_{2} \mathrm{O}$ in raw material should be greater than $5 \mathrm{wt}$. \% [15].

Nanosilica is used in cement paste to mitigate HTHP strength deterioration problems, but it does not perform well under HTHP conditions [16]. The low incorporation of nanosilica also limits the application of this material in long aged set cement because of the insufficient silica source for continuous pozzolanic reaction, resulting in less $\mathrm{C}-\mathrm{S}-\mathrm{H}$ gel being generated in this reaction to combat strength degradation at HTHP. The pozzolanic reaction is reported to characterize the reaction among pozzolans, such as silica flour, calcium hydroxide, generated from the hydration of clinker $\mathrm{C}_{3} \mathrm{~S}$ and $\mathrm{C}_{2} \mathrm{~S}$, and water, as described by Equations 1-3 [17]. Silica flour is promising in this field for high substitution of cement up to $35 \%$ BWOC, while research focused on the influence of the particle size of silica flour on OWC paste is very scarce $[3,4,7]$.

$$
\begin{gathered}
2 \mathrm{C}_{3} \mathrm{~S}+6 \mathrm{H} \rightarrow \mathrm{C}-\mathrm{S}-\mathrm{H} \text { gel }+\mathrm{CH} \\
2 \mathrm{C}_{2} \mathrm{~S}+4 \mathrm{H} \rightarrow \mathrm{C}-\mathrm{S}-\mathrm{H} \text { gel }+\mathrm{CH} \\
\text { Pozzolan }+\mathrm{CH}+\mathrm{H} \rightarrow \mathrm{C}-\mathrm{S}-\mathrm{H} \text { gel }
\end{gathered}
$$

The size of silica influences the pozzolanic reaction and the solution of silica in the OWC slurry. Nanosilica promotes pozzolanic interaction between nanosilica and calcium hydroxide to produce large amounts of amorphous $\mathrm{C}-\mathrm{S}-\mathrm{H}$ gel, fills pores among the $\mathrm{C}-\mathrm{S}-\mathrm{H}$ gel and acts as the center of crystal formation of hydrated cement $[18,19]$. Fine silica flour, with a high rate of solution, results in the formation of a high strength and low permeability phase (xonotlite), while course silica leads to a low strength and high permeability phase (kilchoanite) [20].

The cited studies contain important information, but additional analysis can contribute further. Therefore, a more systematic study is necessary using various measurements, such as XRD, MIP, TG/DTG and SEM/ EDS. This study investigated the effects of the particle size of silica, the addition of silica and the curing time on SSPC at HTHP.

\section{EXPERIMENTAL}

\section{Materials}

API Class G OWC was obtained from Shandong Shengwei Enterprise Company (Linqu, China). Table 1 shows the chemical composition determined using the $\mathrm{X}$-ray fluorescence (XRF) method and the mineral composition calculated using Bogue's equation [21]. Three classes of silica flour (labeled S1, S2 and S3) were supplied by the Fengyang Tengfei quartz sand factory (Anhui, China). The antifoaming agent used for the purpose of removing bubbles generated in the process of agitating cement pastes was commercially available tributyl phosphate. Figure 2 shows the particle size distribution of OWC and silica flour, as measured using a laser diffraction particle size analyzer (Microtrac S3500, US). The median particle sizes $\left(\mathrm{d}_{50}\right)$ of OWC, S1, S2 and $\mathrm{S} 3$ are $15.16 \mu \mathrm{m}, 63.13 \mu \mathrm{m}, 48.25 \mu \mathrm{m}$ and $3.25 \mu \mathrm{m}$, respectively.

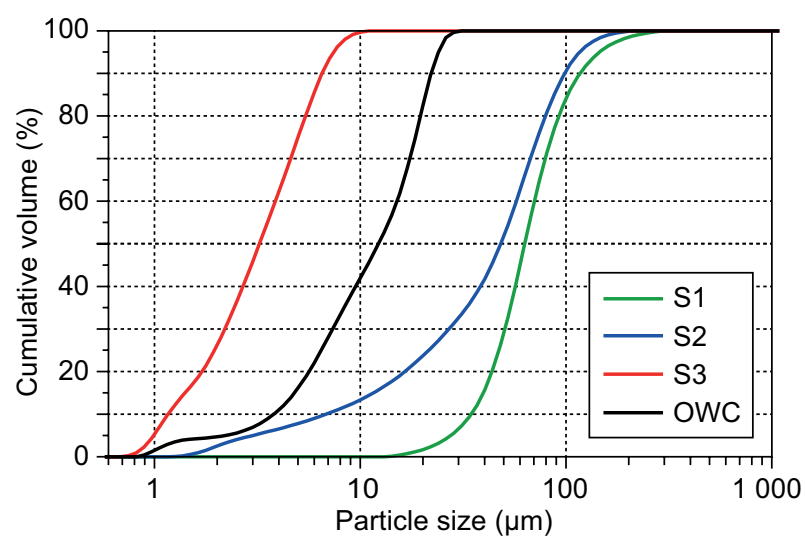

Figure 2. Particle size distribution of OWC and three types of silica flour.

\section{Synthesis of pastes}

Table 2 shows the mix proportions of the "silicastabilized" cement pastes. S1-S3 at 11-67 \% BWOC were incorporated into the paste. OWC pastes with S1-S3 addition with different concentrations of silica, $11 \%, 25 \%, 43 \%$ and $67 \%$ BWOC, were prepared, as was the standard slurry (S0) composed of water, OWC and defoamer.

All pastes were added to $0.25 \mathrm{ml}$ antifoaming agent (tributyl phosphate) and then mixed by a Chandler 3260 mixer, based on the specific norm for cementing oil

\begin{tabular}{|c|c|c|c|c|c|c|c|c|c|}
\hline \multicolumn{6}{|c|}{ Chemical composition (wt. \%) } & \multicolumn{4}{|c|}{ Mineralogical composition (wt. \%) } \\
\hline $\mathrm{SiO}_{2}$ & $\mathrm{Al}_{2} \mathrm{O}_{3}$ & $\mathrm{Fe}_{2} \mathrm{O}_{3}$ & $\mathrm{CaO}$ & $\mathrm{MgO}$ & $\mathrm{SO}_{3}$ & $\mathrm{C}_{3} \mathrm{~S}$ & $\mathrm{C}_{2} \mathrm{~S}$ & $\mathrm{C}_{4} \mathrm{AF}$ & $\mathrm{C}_{3} \mathrm{~A}$ \\
\hline 21.62 & 3.79 & 3.97 & 61.98 & 2.85 & 2.04 & 51.05 & 23.47 & 12.08 & 3.33 \\
\hline
\end{tabular}
wells [22]. After completion of the slurry, it was poured

Table 1. Chemical and mineral compositions of OWC. 
into a metallic mold $\left(5 \times 5 \times 5 \mathrm{~cm}^{3}\right)$ for curing for the designated time. To simulate the down-hole conditions of well cementing, the formulations in Table 2 were evaluated in two distinct scenarios under laboratory conditions: (a) initial hydrothermal curing in a water bath at $80 \pm 0.5^{\circ} \mathrm{C}$ for 7 days and (b) HTHP curing in an autoclave chamber at $260 \pm 10{ }^{\circ} \mathrm{C} \times 21 \pm 1 \mathrm{MPa}$ for 7 days and 28 days. In the HTHP scenarios, the specimens were heated from room temperature to $260{ }^{\circ} \mathrm{C}$ at a heating rate of $20{ }^{\circ} \mathrm{C} / \mathrm{h}$. The pressure in the autoclave chamber was controlled by the decompression valve and booster pump to reach a stable value of $21 \pm 1 \mathrm{MPa}$. After this stage, specimens were removed from the autoclave chamber after naturally cooling to $80 \pm 10^{\circ} \mathrm{C}$ (the suitable temperature to open the autoclave chamber), and the pressure decreased to the ordinary pressure.

Table 2. Mix proportions of cement pastes with silica flour addition.

\begin{tabular}{|c|c|c|c|c|c|}
\hline \multirow[t]{2}{*}{ Samples } & \multirow{2}{*}{$\begin{array}{c}\text { Water } \\
(\mathrm{g})\end{array}$} & \multirow{2}{*}{$\begin{array}{c}\text { OWC } \\
(\mathrm{g})\end{array}$} & \multicolumn{2}{|c|}{ Silica flour } & \multirow{2}{*}{$\begin{array}{l}\text { Water/ } \\
\text { /Cement }\end{array}$} \\
\hline & & & $\overline{(B W O C} \%)$ & (g) & \\
\hline S0 & 264.19 & 601.73 & - & - & 0.44 \\
\hline $11 \mathrm{~S} 1$ & 264.42 & 541.74 & 11 & 59.36 & 0.49 \\
\hline $25 \mathrm{~S} 1$ & 263.19 & 478.37 & 25 & 121.54 & 0.55 \\
\hline $43 \mathrm{~S} 1$ & 264.68 & 419.76 & 43 & 178.78 & 0.63 \\
\hline $67 \mathrm{~S} 1$ & 263.67 & 359.97 & 67 & 239.67 & 0.73 \\
\hline $11 \mathrm{~S} 2$ & 263.48 & 541.43 & 11 & 61.47 & 0.49 \\
\hline $25 \mathrm{~S} 2$ & 264.50 & 479.56 & 25 & 119.49 & 0.55 \\
\hline $43 \mathrm{~S} 2$ & 264.89 & 422.11 & 43 & 181.49 & 0.63 \\
\hline $67 \mathrm{~S} 2$ & 264.16 & 359.54 & 67 & 239.46 & 0.73 \\
\hline $11 \mathrm{~S} 3$ & 263.84 & 539.67 & 11 & 61.34 & 0.49 \\
\hline $25 \mathrm{~S} 3$ & 263.67 & 482.45 & 25 & 119.98 & 0.55 \\
\hline $43 \mathrm{~S} 3$ & 264.62 & 418.46 & 43 & 180.37 & 0.63 \\
\hline $67 \mathrm{~S} 3$ & 263.73 & 359.78 & 67 & 238.89 & 0.73 \\
\hline
\end{tabular}

\section{Characterizations}

Compression tests were performed on three specimens of each slurry under the two scenarios on a universal mechanical testing machine (Hualong WHY-200, China) according to the American Petroleum Institute procedure [23].

The samples for XRD and thermogravimetry analyses were initially ground into powders and then dried at $60{ }^{\circ} \mathrm{C}$ for 4 hours before testing. X-ray diffraction patterns were collected on a diffractometer (Rigaku D/ MAX-RB, Japan) using $\mathrm{Cu} \mathrm{K \alpha}$ radiation, a voltage of $40 \mathrm{kV}$ and a current of $30 \mathrm{~mA}$. The scanning angle ranged from 5 to $80 \% / 2 \theta$, with a scanning rate of $10 \% \mathrm{~min}$. TG/DTG was conducted on a thermobalance (DSC1, Switzerland) under $30 \mathrm{ml} \mathrm{min} \mathrm{m}^{-1}$ air from room temperature to $800{ }^{\circ} \mathrm{C}$ at a heating rate of $10^{\circ} \mathrm{C} / \mathrm{min}$.

The samples were crushed for microstructure and pore structure analyses. Before testing, they were dried at $60{ }^{\circ} \mathrm{C}$ for 4 hours. This drying temperature $\left(60{ }^{\circ} \mathrm{C}\right)$ was thought to have little effect on the pore structure, which is important for maintaining the microstructure and pore structure during the drying process [24]. SEM/EDS analyses were carried out on a scanning electron microscope (JSM 6510, Japan) with a voltage of $15 \mathrm{kV}$. Pore structure tests were conducted using a mercury intrusion porosimeter (PoreMaster GT-60, US). The intrusion pressure ranged from $7.6 \times 10^{-3} \mathrm{MPa}$ (1.1 psi) to 206.6 MPa (29964.7 psi).

\section{RESULTS AND DISCUSSION}

\section{Compressive strength}

The compressive strengths of the OWC pastes as a function of the silica content and particle size are shown in Figure 3.

Figure 3 shows the compressive strengths of cement pastes after 7 days of curing at $80^{\circ} \mathrm{C}$. As shown in Figure 3a, the compressive strength of cement pastes decreases as the proportion of silica flour S1 and S2 increases, in contrast to the samples with silica flour S3 addition, which present higher strength even than the standard sample (S0) at a low incorporation (11 and $25 \%$ BWOC). The reason for this phenomenon may be the small particle size of silica flour S3, which means a larger specific surface than silica flour S1 and S2 for the pozzolanic reaction between silica flour and calcium hydroxide, leading to more production of $\mathrm{C}-\mathrm{S}-\mathrm{H}$ gel to generate strength [17]. In addition, the compressive strength of samples is observed to progressively increase at the respective substitutions as the particle size of the silica flour becomes finer (from S1 to S3). This result suggests that large-size silica flour participates in the pozzolanic reaction to a very low degree and does not effectively decrease the lime-to-silica ratio at $80{ }^{\circ} \mathrm{C}$.

Figure 4 shows the compressive strengths of cement pastes after 7 days of curing at $260^{\circ} \mathrm{C}$ and $21 \mathrm{MPa}$. The compressive strength of the standard sample declines $92.5 \%$ from the condition of $80{ }^{\circ} \mathrm{C}(34.18 \mathrm{MPa})$ to that of $260{ }^{\circ} \mathrm{C}(2.56 \mathrm{MPa})$ at the same curing time (7 days). This phenomenon is referred to as strength retrogression, which occurs above $110^{\circ} \mathrm{C}$ and intensifies with increasing temperature [17]. This decrease in strength is due to the adverse effect of high temperature on the Portland cement hydrated products, resulting in strength retrogression [5]. The anti-retrogression performance of silica flour in cement paste is completely different at low and high incorporation. Marginal increases compared with the standard sample (S0) are observed in the compressive strengths of the 11 and $25 \%$ BWOC silica flour-incorporated samples, while those of the 43 and $67 \%$ BWOC silica flour-modified samples display remarkable increases, because insufficient silica flour substitution in cement does not provide a sufficient silica source for mitigating the strength decline. The addition of silica flour (S1-S3) with $3.25-63.13 \mu \mathrm{m}$ median particle sizes effectively mitigates the strength 
degradation. The samples with $43-67 \%$ silica flour addition exhibit compressive strength values up to 15 times higher than that of the pure cement sample. This result means that silica flour has participated in the pozzolanic reaction and likely changed the composition

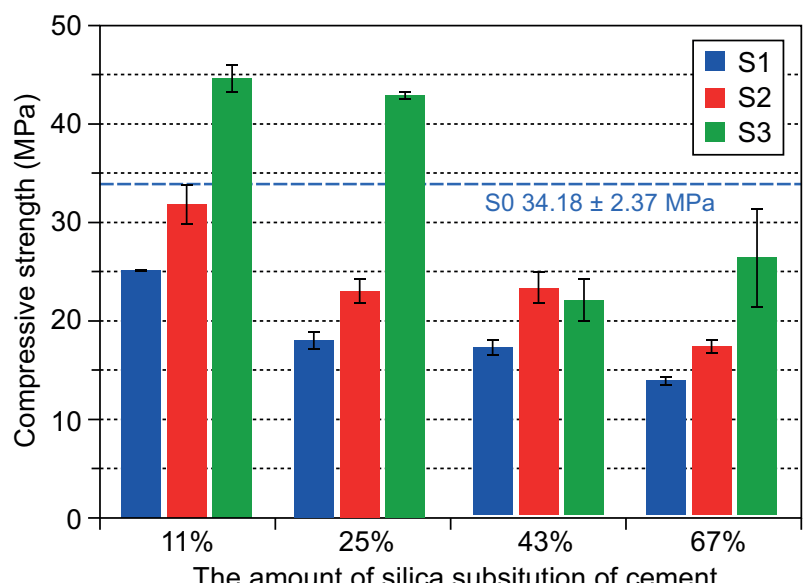

a)

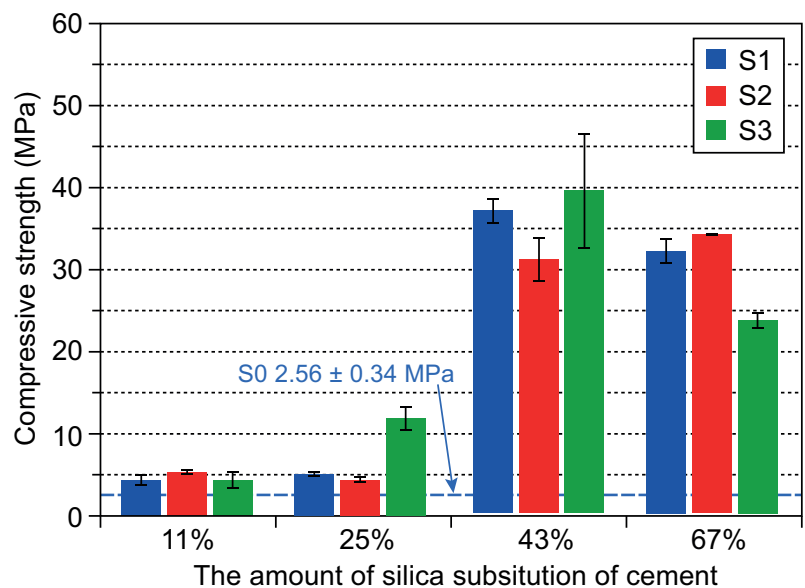

b)

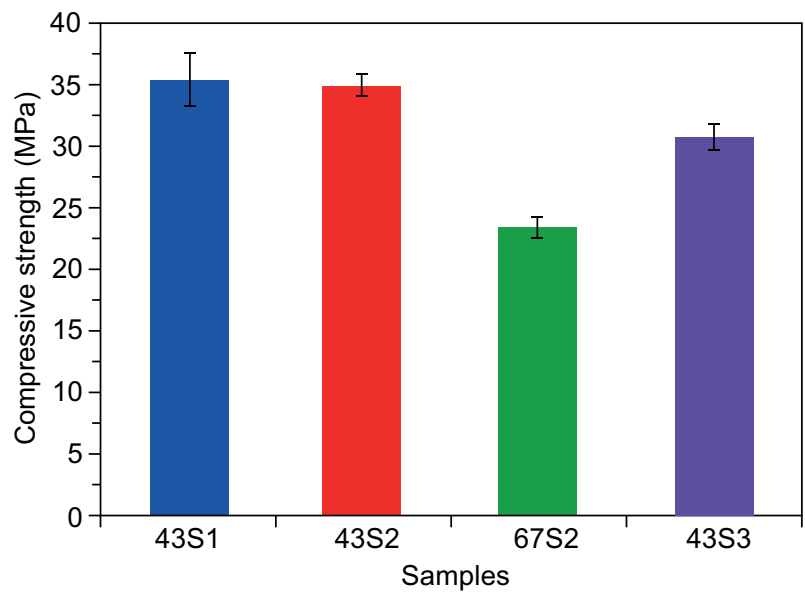

c)

Figure 3. Compressive strength of samples cured at: a) $80{ }^{\circ} \mathrm{C}$ for 7 days, b) $260^{\circ} \mathrm{C} \times 21 \mathrm{MPa}$ for 7 days and c) 28 days. of hydrated phases [25]. In the previous literature, $35 \%$ BWOC was recommended as the optimal incorporation of silica flour, suggesting that values above this one lead to worse strength degradation-combating effects, which is consistent with the results of the samples with silica flour S1 and S3 incorporation but not with those of the sample modified with silica flour S2 [26, 27]. To further evaluate the abnormal phenomena, we prolonged the curing time to 28 days for samples with $67 \%$ BWOC silica flour S2 incorporation.

The compressive strengths of samples exposed to 28 days of HTHP curing are shown in Figure $3 \mathrm{c}$. Comparing the compressive strengths of the samples in Figures $3 \mathrm{c}$ and $3 \mathrm{~b}$ subjected to $260{ }^{\circ} \mathrm{C}$ and $21 \mathrm{MPa}$ between 28 days and 7 days, the strengths of the samples with $43 \%$ BWOC silica flour S1, S2 and S3 incorporation decrease $4.8 \%, 11.6 \%$ and $22.6 \%$, respectively. This result indicates that the optimal particle size of silica flour should be $63.13 \mu \mathrm{m}$ (median particle size of S1), which is coarser than the universally adopted 325 mesh $(45 \mu \mathrm{m})[1,8,26,27]$, suggesting that very fine silica flour may not be a good choice for the anti-retrogression performance of cement slurry in the HTHP environment. The samples with $43 \%$ and $67 \%$ BWOC silica flour S2 incorporation show $11.6 \%$ and $31.8 \%$ compressive strength loss after curing at HTHP from 7 to 28 days because the higher silica flour amounts exceed the amount required for the reaction [28].

\section{Mineral composition}

Figure 4 depicts the DTG curves and mass loss fractions obtained for samples cured under $80^{\circ} \mathrm{C}$ hydrothermal conditions for 7 days as a function of the different particle sizes of silica flour. Three significant peaks can be observed in Figure 4a, which represent three dehydration reactions: removal of physically and chemically bound water from the formed gel structure $\left(<250{ }^{\circ} \mathrm{C}\right)$, dehydration of calcium hydroxide $\left(400-500{ }^{\circ} \mathrm{C}\right)$ and decomposition of calcite $\left(\mathrm{CaCO}_{3}\right)$ into $\mathrm{CaO}$ and $\mathrm{CO}_{2}\left(600-700{ }^{\circ} \mathrm{C}\right)[29]$.

As indicated in Figure $4 b$, the mass loss fractions of the first and second peaks increase and decrease, respectively, with the particle size of the silica flour becoming finer (from S1 to S3). This result suggests that the addition of fine silica flour leads to the formation of an additional gel phase because calcium hydroxide is consumed in the pozzolanic reaction to generate the $\mathrm{C}-\mathrm{S}-\mathrm{H}$ phase. This observation agrees well with our previous speculation that the pozzolanic reaction occurs in pastes with low incorporation of silica flour at $80{ }^{\circ} \mathrm{C}$. The mass loss fraction between 600 and $700{ }^{\circ} \mathrm{C}$ is assigned to the decomposition of calcite. The mass fraction of calcite decreases as the particle size of the silica flour becomes finer, indicating that more calcium is released from the decomposition reaction to the solution for the formation of the gel phase [30]. 


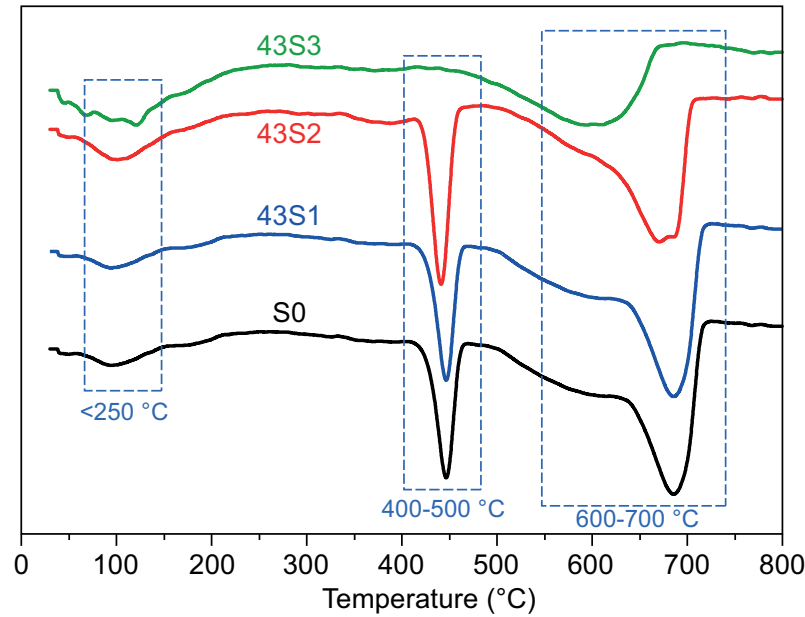

a)

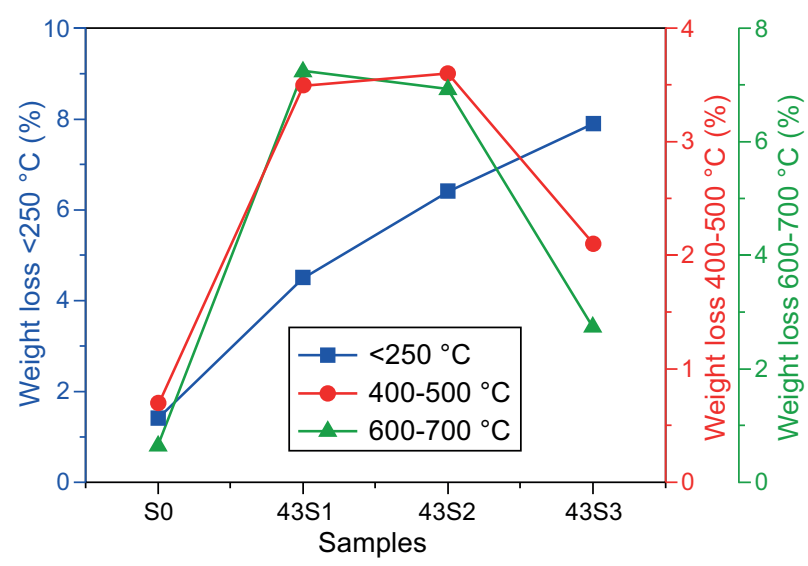

b)

Figure 4. DTG curves of samples cured for 7 days at $80^{\circ} \mathrm{C}$.

The XRD patterns of samples exposed to $80{ }^{\circ} \mathrm{C}$ for 7 days are shown in Figure 5. Two strong diffraction peaks are observed. The one at $2 \theta=18.1^{\circ}$ is the main peak of portlandite, and the other at $26.7^{\circ}$ is that of quartz. The intensity of the major peak located at $18.1^{\circ}$ decreases as the particle size of the silica flour becomes finer, suggesting that silica flour of small particle size is better than large-size silica flour for consumption of portlandite in the pozzolanic reaction to generate more gel phase. This result is consistent with our previous TGA results.

Figure 6 compares the XRD patterns of the samples with silica flour incorporation and the standard sample cured at $260^{\circ} \mathrm{C}$ and $21 \mathrm{MPa}$ from 7 days to 28 days.

Figure 6 a shows the XRD patterns obtained from samples after 7 days of curing at HTHP. Xonotlite is observed in samples $43 \mathrm{~S} 3$ and $67 \mathrm{~S} 2$, which is thought to be a prominent $\mathrm{C}-\mathrm{S}-\mathrm{H}$ phase at high temperature $\left(150{ }^{\circ} \mathrm{C}\right)$ [31]. The following phases are observed in both S0 and 43S1: portlandite and quartz. The appearance of portlandite and quartz peaks in sample 43S1 indicates that the pozzolanic reaction has not been completed, in contrast to the disappearance of these peaks in sample

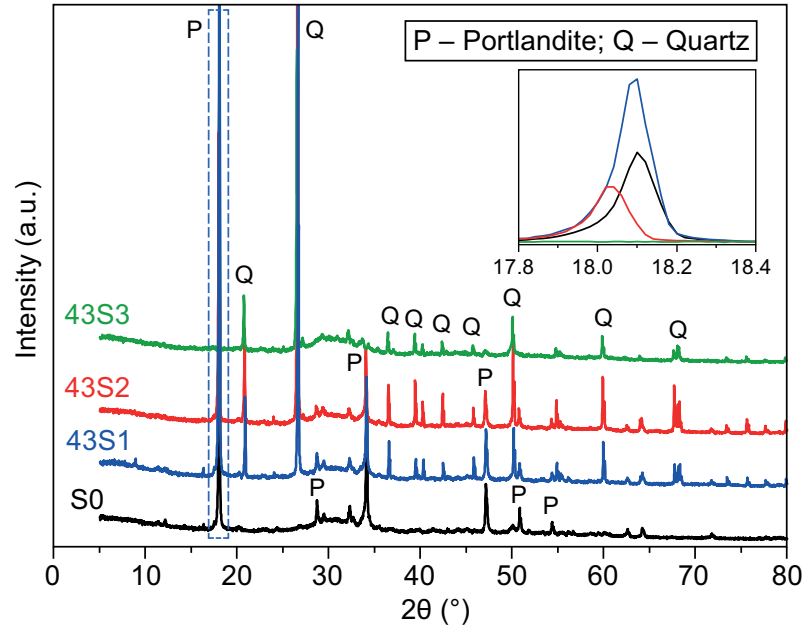

Figure 5. XRD spectra with qualitative analysis of the major phases for specimens cured for 7 days at $80{ }^{\circ} \mathrm{C}$. Phases identified: portlandite, $\mathrm{Ca}(\mathrm{OH})_{2}$, PDF No. 81-2040; quartz, $\mathrm{SiO}_{2}$, PDF No. 77-1060.

43S1 after curing for 28 days at HTHP (Figure 6b). The dicalcium silicate phase in sample $43 \mathrm{~S} 1$ is probably of the $\gamma$-dicalcium silicate type. This phase was formed from $\beta$-dicalcium silicate, the most important component of Portland cement, reacting with $\mathrm{H}_{2} \mathrm{O}$ under hydrothermal conditions. The $\gamma$-dicalcium silicate hydrate decomposed to form reinhardbraunsite and kilchoanite as the reaction proceeded, which is consistent with the kilchoanite trace in the same sample 43S1 [35]. The kilchoanite phase has been frequently encountered in the evaluation of cement paste with the addition of coarse silica flour at elevated temperatures [20]. The feature of the reinhardbraunsite phase in the standard sample (S0) agrees well with the results given by De Sena Costa et al. in terms of their XRD analysis of a standard sample submitted to a thermal cycle at $300{ }^{\circ} \mathrm{C}[5]$.

As shown in Figure $6 \mathrm{a}$, the phase compositions of the samples modified with silica flour change to nearly all xonotlite phase as the silica flour becomes finer, transforming from a low strength and high permeability phase, such as kilchoanite and dicalcium silicate hydrate, and a large amount of unreacted quartz and portlandite to a high strength and low permeability phase (xonotlite) [32-34]. This result indicates that fine silica flour was consumed at a higher rate than course silica flour and accelerates the pozzolanic reaction.

The mineralogical compositions of the 28 day HTHP curing samples analyzed by XRD are shown in Figure $6 \mathrm{~b}$. Only the xonotlite phase is observed in the four samples, and the residual quartz in sample 67S2 occurs because of the addition of too much silica flour. Interestingly, the intensity of the peak at $25.5^{\circ}$ increases to the highest for sample $43 \mathrm{~S} 2$ as the particle size of the silica flour in the cement pastes becomes finer (S1 to S3). This observation indicates that the crystallinity of xonotlite on the (002) crystal plane (corresponding to 


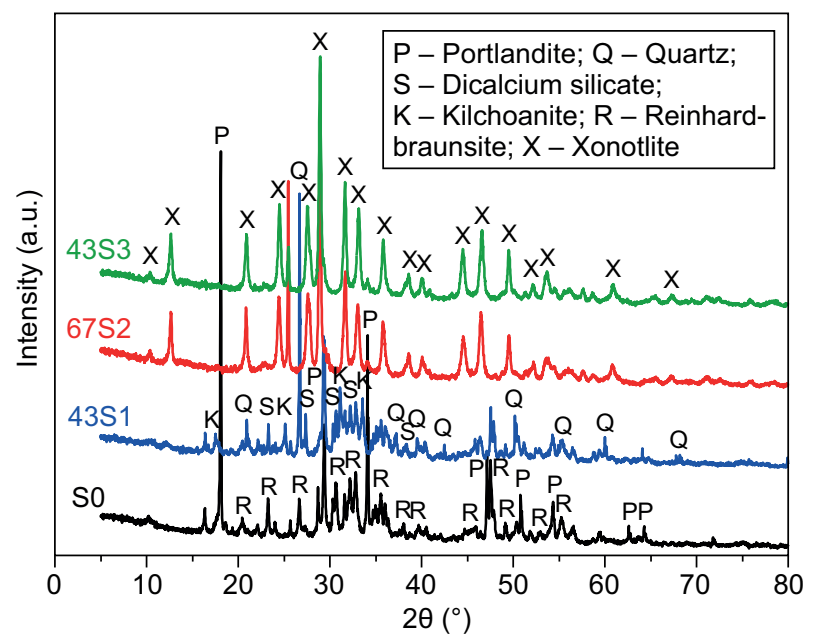

a)

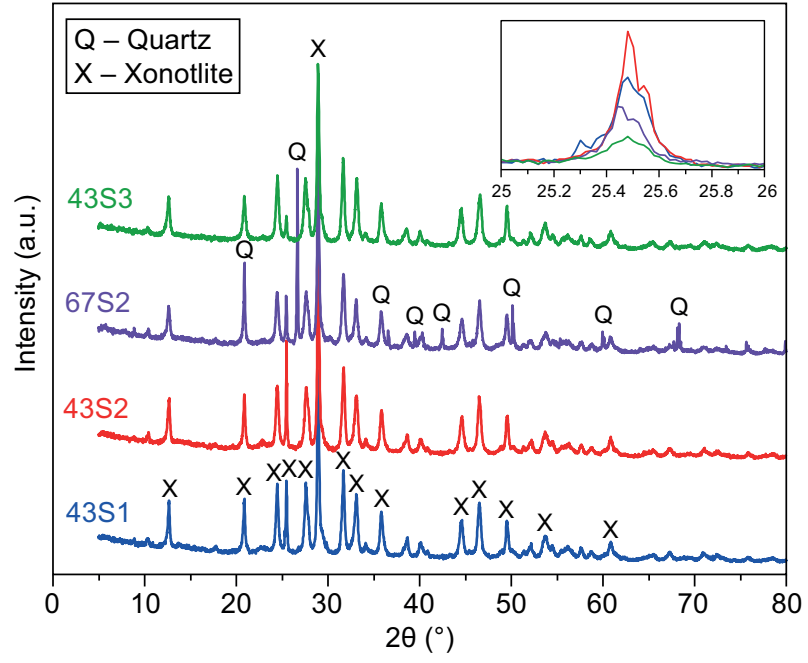

b)

Figure 6. XRD patterns of samples cured at $260{ }^{\circ} \mathrm{C}$ and $21 \mathrm{MPa}$ for: a) 7 days and b) 28 days. Phases identified: portlandite, $\mathrm{Ca}(\mathrm{OH})_{2}$, PDF No. 81-2040; quartz, $\mathrm{SiO}_{2}$, PDF No. 77-1060; dicalcium silicate, C2S, PDF No. 24-0234; kilchoanite, $\mathrm{Ca}_{6}\left(\mathrm{SiO}_{4}\right)$ $\left(\mathrm{Si}_{3} \mathrm{O}\right)$, PDF No. 29-0370; reinhardbraunsite, $\mathrm{Ca}_{5}\left(\mathrm{SiO}_{4}\right)_{2}(\mathrm{OH})_{2}$, PDF No. 84-0148; xonotlite, $\mathrm{Ca}_{6} \mathrm{Si}_{6} \mathrm{O} 17(\mathrm{OH})_{2}$, PDF No. $23-0125$.

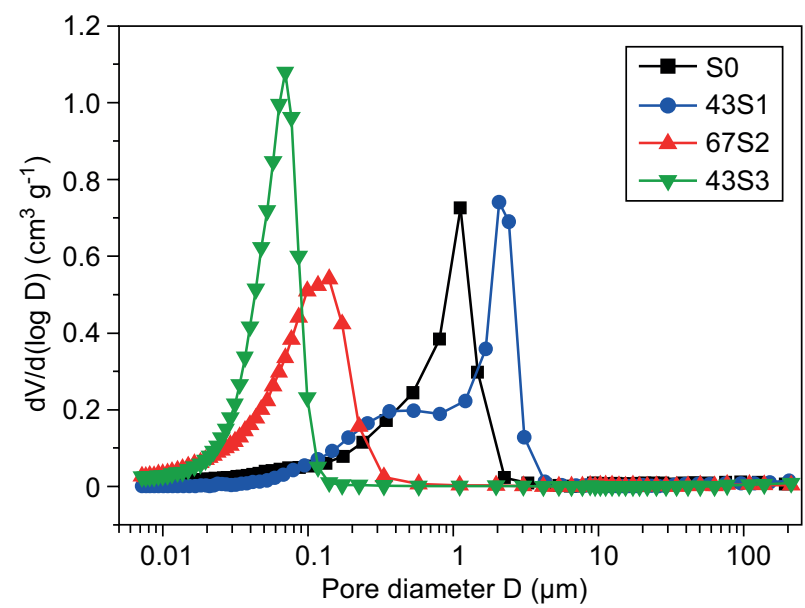

a)

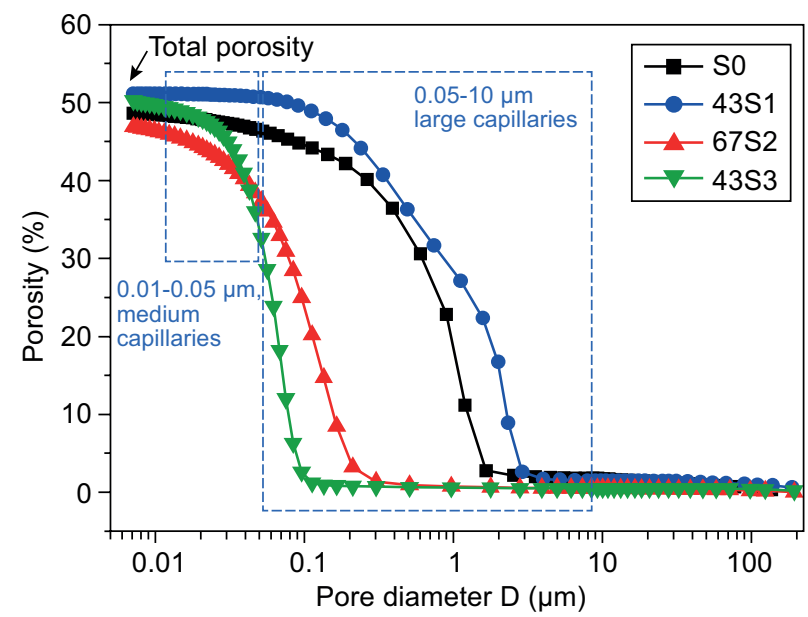

c)

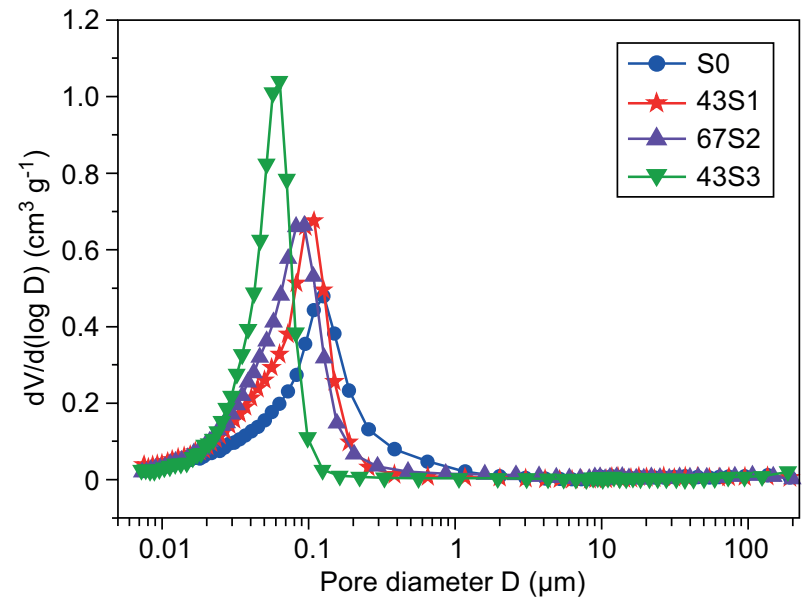

b)

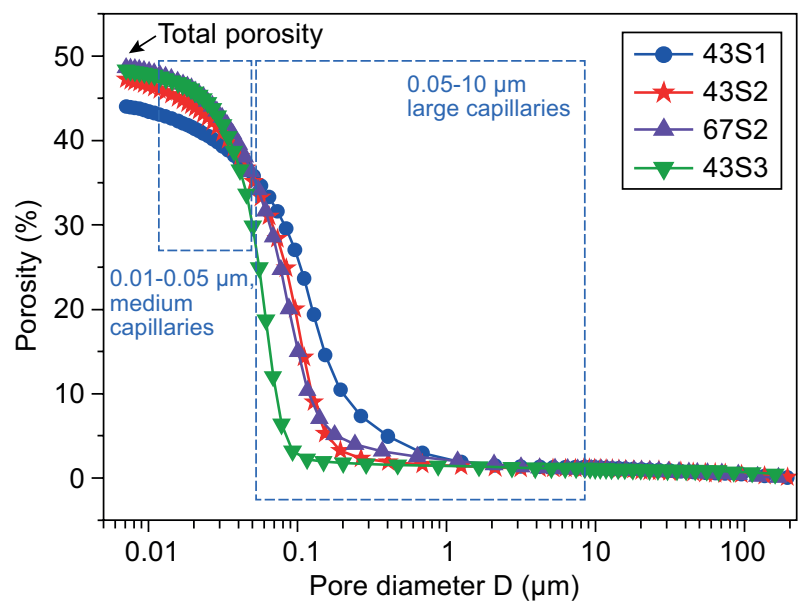

c)

Figure 7. Pore size and porosity distribution of samples cured at $260{ }^{\circ} \mathrm{C}$ and $21 \mathrm{MPa}$ for: a), c) 7 days and b), d) 28 days. 
the $25.5^{\circ}$ diffraction angle of xonotlite) is influenced by the silica flour particle size. Krakowiak et al. reported similar phenomena for tobermorite (a precursor of xonotlite) in silica flour-stabilized cement as the hightemperature hydrothermal curing duration increased from 1 week to 6 months [27].

\section{Pore structure analysis}

The pores in the samples are classified into three classes: gel pores $(<0.01 \mu \mathrm{m})$, formed between the $\mathrm{C}-\mathrm{S}-\mathrm{H}$ gels; medium capillary pores $(0.01-0.05 \mu \mathrm{m})$; and large capillaries $(0.05-10 \mu \mathrm{m})[26,27]$. The pore evolution determines the performance of different size silica flour in OWC pastes. The pore results collected from samples cured under HTHP for different times are presented in Figure 7.

As shown in Figure $7 \mathrm{a}$ and $7 \mathrm{~b}$, the pores of sample 43S1 remarkably decreased, while those of samples $67 \mathrm{~S} 2$ and 43S3 were maintained at a very low level as the curing was prolonged. This result occurred due to the proceeding of the pozzolanic reaction of sample $43 \mathrm{~S} 1$ during the period of 7 days to 28 days, while samples $67 \mathrm{~S} 2$ and $43 \mathrm{~S} 3$ had completed this reaction within 7 days. This finding agrees with the previous XRD results.

Figure $7 \mathrm{c}$ and $7 \mathrm{~d}$ displays the pore size distribution of samples after 7 and 28 days of curing at HTHP. Samples 43S2 and 67S2 have similar pore size distributions (see Figure 7d), meaning that the amount of silica flour does not affect the pozzolanic reaction of SSPC at HTHP. Table 3 gives the detailed results for Figure $7 \mathrm{c}$ and $7 \mathrm{~d}$. The total porosity of sample 43S1 decreases $16.2 \%$, while those of samples $67 \mathrm{~S} 2$ and $43 \mathrm{~S} 3$ present slight fluctuations. This phenomenon is the result of the pozzolanic reaction in sample 43S1, forming a large amount of $\mathrm{C}-\mathrm{S}-\mathrm{H}$ gel for transformation to the xonotlite phase, which is stable at high temperatures $[36,37]$. This result is consistent with the XRD results, which detected the xonotlite phase in sample 43S1. The pore structure of the SSPC is dependent on the silica flour particle size. Comparing the pore structures of each sample in Table 3 from 7 to 28 days, they present an increasing trend in the porosity of medium capillary pores and a decreasing trend in the porosity of large capillary pores. This phenomenon can be attributed to the pozzolanic reaction of silica flour and calcium hydroxide, in which the portion of silica flour in contact

Table 3. Comparison of the porosities of samples cured at $260{ }^{\circ} \mathrm{C}$ and $20 \mathrm{MPa}$ from 7 to 28 days.

\begin{tabular}{lrrrrrrrr}
\hline Specimens & \multicolumn{2}{c}{$43 \mathrm{~S} 1$} & & \multicolumn{2}{c}{$67 \mathrm{~S} 2$} & & \multicolumn{2}{c}{$43 \mathrm{~S} 3$} \\
\cline { 2 - 3 } Time (d) & \multicolumn{1}{c}{28} & & \multicolumn{1}{c}{7} & 28 & & 7 & 28 \\
\hline Total porosity (\%) & 51.1 & 42.8 & & 46.7 & 47.6 & & 49.9 & 47.2 \\
Med. capillaries (\%) & 0.4 & 7.65 & & 8.9 & 11.8 & & 17.1 & 18.0 \\
Large capillaries (\%) & 49.8 & 34.6 & & 37.2 & 35.3 & & 32.2 & 28.8 \\
\hline
\end{tabular}

with calcium hydroxide is consumed, leaving pores on the silica flour surface. The $\mathrm{C}-\mathrm{S}-\mathrm{H}$ gel generated in the pozzolanic reaction fills the interstices of cement and silica flour particles, decreasing the large capillaries.

\section{SEM-EDS analysis}

Figure 8 presents SEM images of samples 43S1, 43S2 and 43S3 and the obtained EDS results. The 43S1 sample displays a larger pore structure than the 43S3 sample, which is consistent with the previous MIP results.

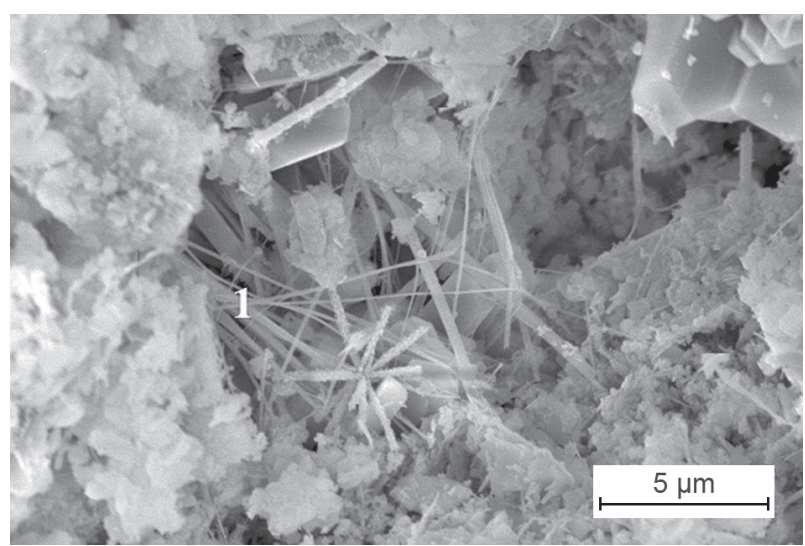

a)

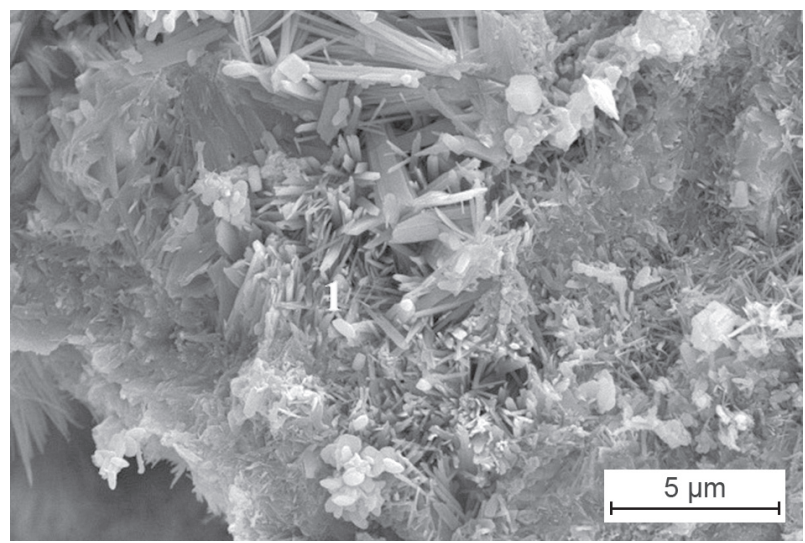

b)

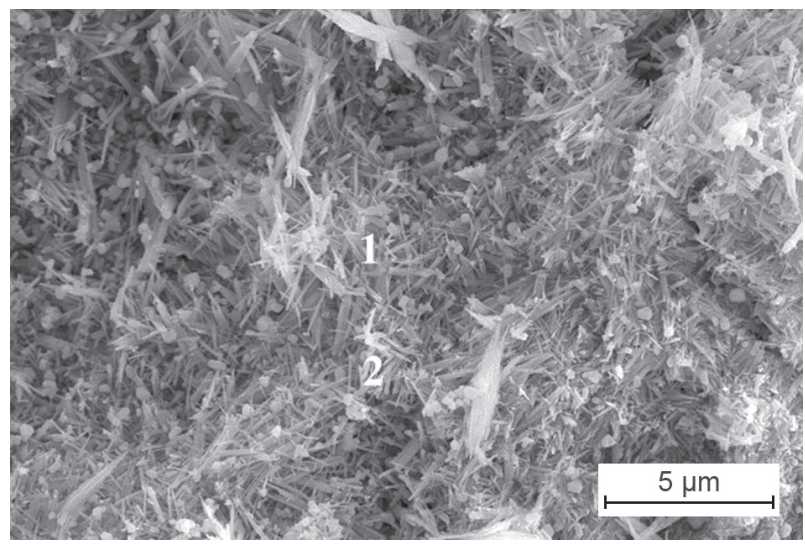

c)

Figure 8. SEM images of samples: a) 43S1, b) $43 \mathrm{~S} 2$ and c) $43 \mathrm{~S} 3$ cured at HTHP for 7 days. (Continue on next page) 


\begin{tabular}{|c|c|c|c|c|c|}
\hline & $\mathrm{C}$ & $\mathrm{O}$ & $\mathrm{Si}$ & $\mathrm{Ca}$ & $\mathrm{Ca} / \mathrm{Si}$ \\
\hline $43 \mathrm{~S} 1-1$ & 44.62 & 13.67 & 3.17 & 28.20 & 8.9 \\
\hline $43 \mathrm{~S} 2-1$ & 27.76 & 33.17 & 16.93 & 22.14 & 1.3 \\
\hline $43 \mathrm{~S} 3-1$ & 20.94 & 43.91 & 14.57 & 20.58 & 1.4 \\
\hline $43 \mathrm{~S} 3-2$ & 29.36 & 33.74 & 16.55 & 20.35 & 1.2 \\
\hline
\end{tabular}

d)

Figure 8. d) EDS analysis results of the whisker composition in samples 43S1, 43S2 and 43S3.

Samples 43S2 and 43S3 are similar in microstructure, while sample $43 \mathrm{~S} 3$ exhibits more whiskers than sample 43S2. The elemental characterization of the whiskers in the SEM images was performed through EDS analysis, and the results are listed in Figure 8d. According to the EDS results shown in Figure 8d, the $\mathrm{Ca} / \mathrm{Si}$ ratio of whiskers in samples $43 \mathrm{~S} 2$ and $43 \mathrm{~S} 3$ is in the range of 1.2 - 1.4, which indicates the same composition for the two samples [38]. Such results confirm the previous $\mathrm{XRD}$ results, which show that this phase is xonotlite.

\section{CONCLUSIONS}

This study investigated the effects of the particle size distribution of silica flour on the thermal stability of SSPC under HTHP conditions. The following conclusions can be drawn:

- The addition of ultrafine silica flour $(3.25 \mu \mathrm{m})$ promoted the compressive strength development of SSPC paste during the initial curing stage. The addition of silica flour $(48.25 \mu \mathrm{m}$ and $63.13 \mu \mathrm{m})$ mitigated the compressive strength degradation of SSPC paste during further HTHP aging.

- Ultrafine silica flour $(3.25 \mu \mathrm{m})$ can react with calcium hydroxide in cement paste cured at $80{ }^{\circ} \mathrm{C}$. After 7 days of initial curing, ultrafine silica flour is completely consumed during the hydration of cement paste. When the further aging temperature is $260^{\circ} \mathrm{C}$, the addition of silica $(3.25$ and $48.25 \mu \mathrm{m})$ leads to the formation of xonotlite in SSPC. In addition, the crystallization of xonotlite in SSPC on the (002) crystal plane is unexpectedly influenced by the size of the silica, and $48.25 \mu \mathrm{m}$ silica presents better performance than the other size silica.

- The incorporation of coarse silica flour $\left(\mathrm{d}_{50}=63.13 \mu \mathrm{m}\right)$ into the cement paste is helpful in maintaining the compactness of the pore structure during 28 days of high-temperature curing. The internal large pores in SSPC are partially filled in, forming medium capillaries, as the hydration reaction or pozzolanic reaction proceeds.

\section{Acknowledgments}

The authors acknowledge Yue, C. of the State Key Laboratory of Materials-Oriented Chemical Enginee- ring (Nanjing, China) for supporting sample characterizations, such as MIP and XRF, and for his kind suggestions. In addition, the first author appreciates Renhui, M. for assistance during the experiments and Hui, J. for providing language help.

\section{REFERENCES}

1. Omosebi O., Maheshwari H., Ahmed R., Shah S., Osisanya S., Santra A., Saasen A. (2015): Investigating temperature effect on degradation of well cement in HPHT carbonic acid environment. Journal of Natural Gas Science and Engineering, 26(C), 1344-1362. Doi: 10.1016/j.jngse. 2015.08.018

2. Soares L. W. O., Braga R. M., Freitas J. C. O., Ventura R. A., Pereira D. S. S., Melo D. M. A. (2015): The effect of rice husk ash as pozzolan in addition to cement Portland class $G$ for oil well cementing. Journal of Petroleum Science and Engineering, 131(C), 80-85. Doi: 10.1016/j. petrol.2015.04.009

3. Bu Y., Chang Z., Du J., Liu D. (2017): Experimental study on the thermal expansion property and mechanical performance of oil well cement with carbonaceous admixtures. RSC Advances, 7, 29240-29254. Doi: 10.1039/ C7RA03504G

4. Guo S., Bu Y., Lu Y. (2019): Addition of tartaric acid to prevent delayed setting of oil-well cement containing retarder at high temperatures. Journal of Petroleum Science and Engineering, 172, 269-279. Doi: 10.1016/j.petrol. 2018.09.053

5. de Sena Costa B. L., de Souza G. G., de Oliveira Freitas J. C., da Silva Araujo R. G., Santos P. H. S. (2017): Silica content influence on cement compressive strength in wells subjected to steam injection. Journal of Petroleum Science and Engineering, 158, 626-633. Doi: 10.1016/j. petrol.2017.09.006

6. Taylor H. F. W. (1993): Nanostructure of C-S-H: Current status. Advanced Cement Based Materials, 1(1), 38-46. Doi: 10.1016/1065-7355(93)90006-A

7. Sun X., Wu Q., Zhang J., Qing Y., Wu Y., Lee S. (2017): Rheology, curing temperature and mechanical performance of oil well cement: Combined effect of cellulose nanofibers and graphene nano-platelets. Jmade, 114(C), 92-101. Doi: 10.1016/j.matdes.2016.10.050

8. Ge Z., Yao X., Wang X., Zhang W., Yang T. (2018): Thermal performance and microstructure of oil well cement paste containing subsphaeroidal konilite flour in HTHP conditions. Construction and Building Materials, 172, 787-794. Doi: 10.1016/j.conbuildmat.2018.03.268

9. Hsiang H.-I., Chen W.-S., Huang W.-C. (2015): Pre-reaction temperature effect on $\mathrm{C}-\mathrm{S}-\mathrm{H}$ colloidal properties and xonotlite formation via steam assisted crystallization. Materials and Structures, 1-11. Doi: 10.1617/s11527-0150547-0

10. Gabrovšek R., Kurbus B., Mueller D., Wieker W. (1993): Tobermorite formation in the system $\mathrm{CaO}, \mathrm{C}_{3} \mathrm{~S}-\mathrm{SiO}_{2}-$ $\mathrm{Al}_{2} \mathrm{O}_{3}-\mathrm{NaOH}-\mathrm{H}_{2} \mathrm{O}$ under hydrothermal conditions. Cement and Concrete Research, 23, 321-328. Doi: 10.1016/ 0008-8846(93)90097-S

11. Zou J., Guo C., Jiang Y., Wei C., Li F. (2016): Structure, morphology and mechanism research on synthesizing xonotlite fiber from acid-extracting residues of coal fly 
ash and carbide slag. Materials Chemistry and Physics, 172(C), 121-128. Doi: 10.1016/j.matchemphys.2016.01.050

12. Jiang J., Cui C., Liu J., Liao W. (2011): Hydrothermal synthesis of xonotlite-type calcium silicate insulation material using industrial zirconium waste residue. Journal of Wuhan University of Technology-Mater. Sci. Ed., 26(3), 519-522. Doi: 10.1007/s11595-011-0260-y

13. Méducin F., Bresson B., Lequeux N., Noirfontaine M. N. de, Zanni H. (2007): Calcium silicate hydrates investigated by solid-state high resolution ${ }^{1} \mathrm{H}$ and ${ }^{29} \mathrm{Si}$ nuclear magnetic resonance. Cement and Concrete Research, 37(5), 631-638. Doi: 10.1016/j.cemconres.2007.01.011

14. Black L., Garbev K., Stumm A. (2013): Structure, bonding and morphology of hydrothermally synthesised xonotlite. Advances in Applied Ceramics, 108(3), 137-144. Doi: 10.1179/174367608X353638

15. Liu F., Wang X.-D., Cao J.-X. (2013): Effect of $\mathrm{Na}^{+}$on xonotlite crystals in hydrothermal synthesis. International Journal of Minerals, Metallurgy, and Materials, 20(1), 88-93. Doi: 10.1007/s12613-013-0698-3

16. Wang C., Chen X., Wei X., Wang R. (2017): Can nano-silica sol prevent oil well cement from strength retrogression under high temperature? Construction and Building Materials, 144, 574-585. Doi: 10.1016/j.conbuildmat.2017.03.221

17. Bezerra U. T., Martinelli A. E., Melo D. M. A., Melo M. A. F., Oliveira V. G. (2011): The strength retrogression of special class Portland oilwell cement. Cerâmica, 57(342), 150-154. Doi: 10.1590/S0366-69132011000200004

18. El-Gamal S. M. A., Hashem F. S., Amin M. S. (2017): Influence of carbon nanotubes, nanosilica and nanometakaolin on some morphological-mechanical properties of oil well cement pastes subjected to elevated water curing temperature and regular room air curing temperature. Construction and Building Materials, 146, 531-546. Doi: 10.1016/j.conbuildmat.2017.04.124

19. Choolaei M., Rashidi A. M., Ardjmand M., Yadegari A., Soltanian H. (2012): The effect of nanosilica on the physical properties of oil well cement. Materials Science \& Engineering A, 538, 288-294. Doi: 10.1016/j.msea. 2012.01.045

20. Eilers L. H., Nelson E. B. (1979). Effect Of Silica Particle Size On Degradation Of Silica Stabilized Portland Cement. Presented at the SPE Oilfield and Geothermal Chemistry Symposium. Doi: 10.2118/7875-ms

21. Nelson E. B., Guillot D. (2006). Well Cementing. $2^{\text {nd }}$ ed. Schlumberger, Texas.

22. API Spec 10A. (2000). Specifications for Cements and Materials for Well Cementing. American Petroleum Institute. Dallas.

23. API 2013. (2013). API Recommended Practice 10B-2recommended Practice for Testing Well Cements second ed. American Petroleum Institute. Washington.

24. Yang T., Yao X., Zhang Z. (2014): Geopolymer prepared with high-magnesium nickel slag: Characterization of properties and microstructure. Construction and Building Materials, 59(C), 188-194. Doi: 10.1016/j.conbuildmat. 2014.01.038

25. Le Saout G., Lécolier E., Rivereau A., Zanni H. (2006): Chemical structure of cement aged at normal and elevated temperatures and pressures. Cement and Concrete Research, 36(1), 71-78. Doi: 10.1016/j.cemconres.2004. 09.018

26. Krakowiak K. J., Thomas J. J., Musso S., James S., Akono A.-T., Ulm F.-J. (2015): Nano-chemo-mechanical signature of conventional oil-well cement systems: Effects of elevated temperature and curing time. Cement and Concrete Research, 67, 103-121. Doi: 10.1016/j.cemconres. 2014.08.008

27. Krakowiak K. J., Thomas J. J., James S., Abuhaikal M., Ulm F. J. (2018): Development of silica-enriched cementbased materials with improved aging resistance for application in high-temperature environments. Cement and Concrete Research, 105, 91-110. Doi: 10.1016/j. cemconres.2018.01.004

28. Ulm F.-J., James S. (2011): The scratch test for strength and fracture toughness determination of oil well cements cured at high temperature and pressure. Cement and Concrete Research, 41(9), 942-946. Doi: 10.1016/j.cemconres.2011. 04.014

29. Knop Y., Peled A. (2018): Sustainable Blended Cements Influences of Packing Density on Cement Paste Chemical Efficiency. Materials, 11(4), 625-14. Doi: 10.3390/ma 11040625

30. Yang T., Zhu H., Zhang Z., Gao X., Zhang C., Wu Q. (2018): Effect of fly ash microsphere on the rheology and microstructure of alkali-activated fly ash/slag pastes. Cement and Concrete Research, 109, 198-207. Doi: 10.1016/j.cemconres.2018.04.008

31. Hwang J., Ahmed R., Tale S., Shah S. (2018): Shear bond strength of oil well cement in carbonic acid environment. Journal of $\mathrm{CO}_{2}$ Utilization, 27, 60-72. Doi: 10.1016/j. jcou.2018.07.001

32. Nelson E. B., Eilers L. H., Kalousek G. L. (1981). Formation and behavior of calcium silicate hydrates in a geothermal environment. Cement and Concrete Research, 11(3), 371-381. Doi: 10.1016/0008-8846(81)90109-5

33. Eilers L. H., Nelson E. B., Moran L. K. (1983): HighTemperature Cement Compositions - Pectolite, Scawtite, Truscottite, or Xonotlite: Which Do You Want? Journal of Petroleum Technology, 35(07), 1, 373-1,377. Doi: 10. 2118/9286-PA

34. Alawad O. A., Alhozaimy A., Jaafar M. S., Aziz F. N. A., Al-Negheimish A. (2015): Effect of Autoclave Curing on the Microstructure of Blended Cement Mixture Incorporating Ground Dune Sand and Ground Granulated Blast Furnace Slag. International Journal of Concrete Structures and Materials, 9(3), 381-390. Doi: 10.1007/ s40069-015-0104-9

35. Yanagisawa K., Hu X., Onda A., Kajiyoshi K. (2006): Hydration of $\beta$-dicalcium silicate at high temperatures under hydrothermal conditions. Cement and Concrete Research, 36(5), 810-816. Doi: 10.1016/j.cemconres.2005.12.009

36. Jauberthie R., Temimi M., Laquerbe M. (1996): Hydrothermal transformation of tobermorite gel to $10 \AA$ tobermorite. Cement and Concrete Research, 26(9), 1335-1339. Doi: 10.1016/0008-8846(96)00122-6

37. Alawad O. A., Alhozaimy A., Jaafar M. S., Aziz F. N. A., Al-Negheimish A. (2015): Effect of Autoclave Curing on the Microstructure of Blended Cement Mixture Incorporating Ground Dune Sand and Ground Granulated Blast Furnace Slag. International Journal of Concrete Structures and Materials, 9(3), 381-390. Doi: 10.1007/s40069-0150104-9

38. Konuklu Y., Ersoy O. (2017): Fabrication and characterization of form-stable phase change material/xonotlite microcomposites. Solar Energy Materials and Solar Cells, 168, 130-135. Doi: 10.1016/j.solmat.2017.04.019 